\begin{abstract}
Geomorphological assessments were conducted and passive acoustic recordings were collected from 2012 through 2014 at 3 recently identified spawning aggregations of the black grouper (Mycteroperca bonaci) in Puerto Rico and southern Florida. A time series of courtshipassociated sounds (CASs) by black grouper were analyzed in relation to lunar and diel periodicities, water temperature, and tidal stage. Analysis of CAS recordings indicated similar temporal patterns at the 3 spawning aggregations. Spawning season was correlated with decreased water temperature. Within the spawning season, CAS production was influenced significantly by lunar and diel periodicities and sound production peaked between the last quarter and new moons during evening hours. The data from this study also indicate a potential correlation with tidal stage. Temporal patterns were similar during 3 consecutive years at Mona Island in Puerto Rico and for the geographically isolated sites of Mona Island and Riley's Hump off Florida. At Bajo de Sico in Puerto Rico, courtship activity was lower than that at the other sites but reflected the same general patterns in 2014. For all 3 sites, spawning aggregations were found less than $150 \mathrm{~m}$ from a promontory at depths between 25 and $35 \mathrm{~m}$ near deep water $(>100 \mathrm{~m})$.
\end{abstract}

Manuscript submitted 22 April 2016. Manuscript accepted 17 January 2017. Fish. Bull. 115:186-195 (2017).

Online publication date: 7 February 2017. doi: 10.7755/FB.115.2.5

The views and opinions expressed or implied in this article are those of the author (or authors) and do not necessarily reflect the position of the National Marine Fisheries Service, NOAA.

\title{
Patterns of courtship acoustics and geophysical features at spawning sites of black grouper (Mycteroperca bonaci)
}

\author{
Phillip J. Sanchez (contact author) ${ }^{1}$ \\ Richard S. Appeldoorn' \\ Michelle T. Schärer-Umpierre ${ }^{1}$ \\ James V. Locascio² \\ Email address for contact author: phillip.sanchez@upr.edu \\ 1 Department of Marine Sciences \\ University of Puerto Rico-Mayagüez \\ Carretera 304 End of Road \\ Isla Magueyes \\ La Parguera, Lajas, Puerto Rico 00667 \\ 2 Mote Marine Laboratory \\ 1600 Ken Thompson Parkway \\ Sarasota, Florida 34236
}

Most large, western Atlantic groupers (family Epinephelidae) form site-specific transient fish spawning aggregations (FSAs) at predictable times throughout the year (Domeier and Colin, 1997). Large proportions of the annual catch of species that form transient FSAs occur when these fish are aggregated (Claydon, 2004). Consequently, groupers are vulnerable to intense fishery pressure (Eklund et al., 2000; Brulé et al., 2003). Combined with the protogynous hermaphroditism, slow growth, and late maturation common to large groupers, many species of grouper are experiencing population declines due to the removal of spawning stocks at aggregations (Matos-Caraballo, 1997).

The black grouper (Mycteroperca bonaci) is the second largest grouper in the western Atlantic and is classified as near threatened in the IUCN Red List of Threatened Species because of declining populations (Ferreira et al., 2008). Although black grouper can spawn year-round (Crabtree and Bullock, 1998), the majority of their annual reproductive effort is spent seasonally during transient spawning aggregations (GarcíaCagide and García, 1996; Crabtree and Bullock, 1998). Only 3 spawning aggregations of black grouper have been described within U.S. territorial waters (Eklund et al., 2000; Schärer et al., 2014; Locascio and Burton, 2016). However, black grouper are believed to form many small spawning aggregations throughout their range (Paz and Sedberry, 2008).

Identification, characterization, and assessment of FSAs are critical for effective management of populations (Claydon, 2004). Geomorphological assessments of 5 multispecies FSA sites used by large groupers (with 1 site documented for black grouper) revealed consistent benthic morphometric parameters across sites (Kobara and Heyman, 2008). Furthermore, follow-up analyses of bathymetry maps at 12 known FSA sites in Belize (10 supporting black grouper) led to the documentation of 2 additional multispecies aggregations, both of which included black grouper (Kobara and Heyman, 2010).

Black grouper form spawning aggregations at different times of the 


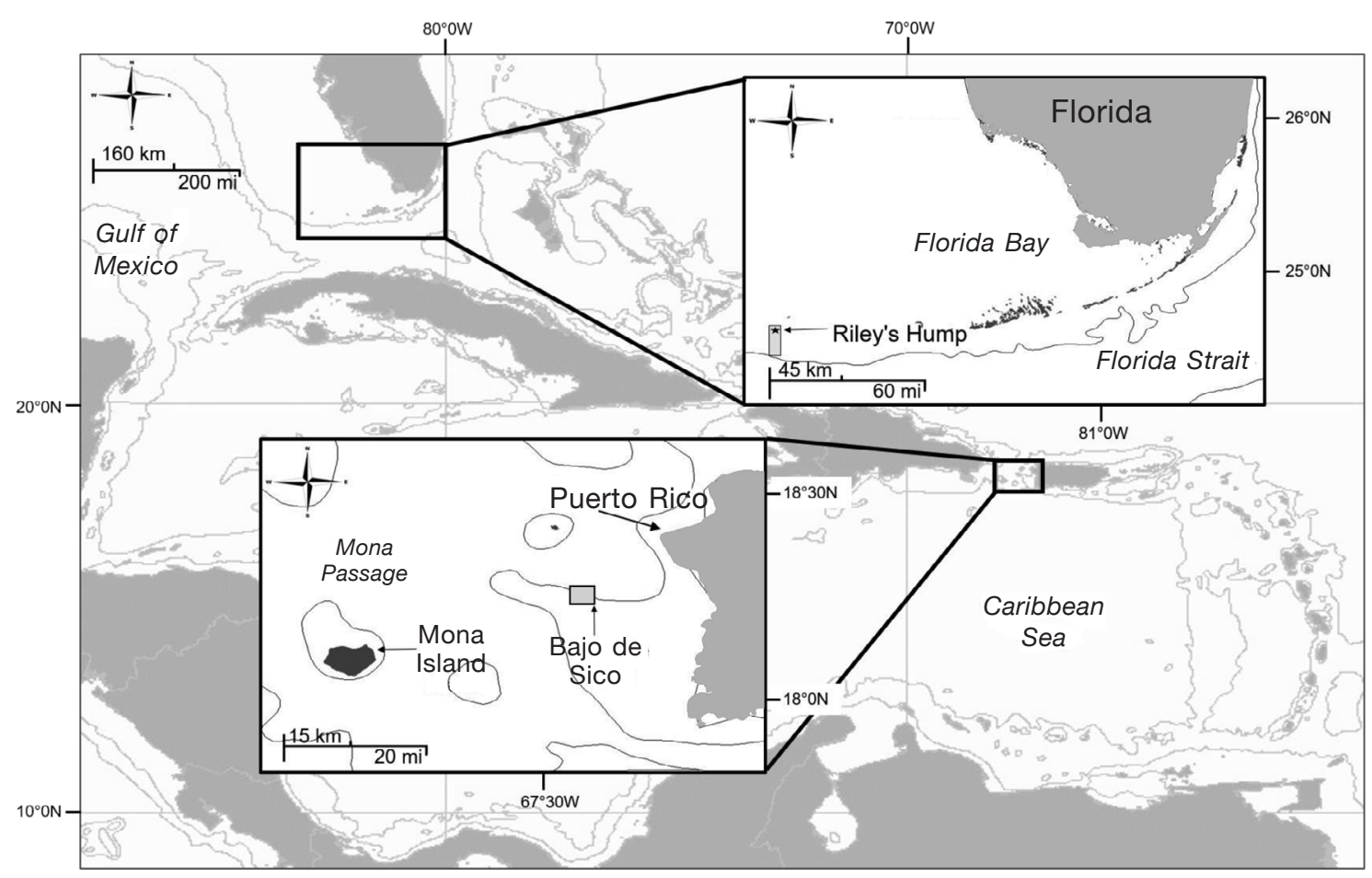

Figure 1

Map of the 3 study sites sampled in this study of acoustic courtship of black grouper (Mycteroperca bonaci) in Puerto Rico and off southern Florida during 2012-2014. Top right excerpt shows the location of Riley's Hump within the Tortugas South Ecological Reserve off southern Florida. Bottom left excerpt shows locations of the Bajo de Sico seasonal no-take reserve and Mona Island off Puerto Rico. Contour lines indicate 200- and 2000-fathom bathymetry.

year throughout their range in water temperatures of $25-28^{\circ} \mathrm{C}$ from the east coast of Brazil, through the Caribbean and Gulf of Mexico, to Bermuda (Brulé et al., 2003; Teixeira et al., 2004; Paz and Sedberry, 2008; Luckhurst, 2010). At aggregations, increases in the number of black grouper correlate with the period between the full moon and new moon and during dusk hours, when the only direct observations of gamete release have been made (Sala et al., 2001; Paz and Sedberry, 2008). Although general temporal patterns are known, the specifics of spawning timing are not, and it is believed that site-specific temporal patterns of spawning are likely to respond to local environmental variations. Passive acoustic monitoring of FSAs of red hind (Epinephelus guttatus) off western Puerto Rico, for example, has shown that peak courtship sound production occurs at different times (Mann et al., 2010; Appeldoorn et al., in press) even between sites located within $12 \mathrm{~km}$ of each other on the same shelf. This observation indicates that the dynamics of FSAs are variable locally - a finding that has implications for best management practices and local conservation measures (e.g., closed seasons).

Courtship sounds are common throughout the epinephelids (Mann et al., 2009, 2010; Nelson et al., 2011, Schärer et al., 2012a, 2012b), and male black grouper are no exception, producing a species-specif- ic courtship sound associated with spawning behavior (Schärer et al., 2014; Locascio and Burton, 2016). With passive acoustic monitoring, therefore, it is possible to conduct a more detailed analysis of the courtship patterns of black grouper than current methods allow (Rowell et al., 2011, 2015). Traditionally, FSAs are monitored by using diver surveys and analysis of gonadal-somatic indices (GSIs). However, passive acoustic monitoring has 3 advantages: 1) field work is not subject to marine conditions or physiological limitations; 2) data collection is long term and occurs on a set recording schedule; and 3 ) multiple sites can be monitored simultaneously (Gannon, 2008; Luczkovich et al., 2008).

Reproductive behavior needs to be understood thoroughly to develop and implement effective management policy. The objectives for this study were 1) to use highresolution acoustic time series to study the interannual variability of temporal patterns at a spawning aggregation of black grouper and intra-annual variability between 2 geographically separate FSAs, 2) to conduct an initial assessment of an undocumented spawning aggregation of black grouper, and 3) to characterize the morphometric parameters of the 3 sites where black grouper aggregate and test whether their geophysical features are consistent with predictions derived from previously described sites. 


\section{Materials and methods}

\section{Study sites}

Mona Island is a carbonate platform located approximately $73 \mathrm{~km}$ west of Cabo Rojo, Puerto Rico (Fig. 1). The Mona and Monito Islands National Reserve extends from the coast out to $17 \mathrm{~km}$ (9 nautical miles); a year-round no-take zone encompasses all waters around the island within $13 \mathrm{~km}$ (7 nautical miles) of shore. The island itself is a flat-topped, raised platform with continuous vertical cliffs around almost the entire perimeter. Along the south-southwestern insular shelf, there is a shallow lagoon bordered by coral reefs along the seaward end (Frank et al., 1998). The spawning aggregation of black grouper at this site is located along the southern shelf edge bordered by a steep reef wall. Courtship interactions, ventral rubbing, and courtship colorations of black grouper were previously recorded at this site in conjunction with courtship-associated sound (CAS) production (Schärer et al., 2014).

Riley's Hump is a small carbonate reef bank to the southwest of the Dry Tortugas within the Tortugas South Ecological Reserve, Florida-a fully protected marine reserve (Fig. 1). This reef bank is a multispecies FSA site and a year-round no-take zone. The bank crest rises to a $30-\mathrm{m}$ depth at its shallowest point, and the southern and western edges of the platform are composed of a steep reef wall (Weaver et al., 2006). This spawning aggregation of black grouper at this site is located on a pinnacle off the southwestern corner of the crest of the seamount. In previous years, courtship interactions of black grouper were documented in combination with recorded CASs along the southern wall (Locascio and Burton, 2016).

Bajo de Sico is a seamount located approximately 27 km west of Mayagüez, Puerto Rico (Fig. 1). A seasonal marine protected area, it is closed to fishing from 1 October to 31 March for all reef fish species regulated by the Caribbean Fishery Management Council. Consisting of $31.2 \mathrm{~km}^{2}$, this seamount is jointly managed by Puerto Rico and U.S. federal jurisdictions. This seamount supports hermatypic corals at depths between 40 and $90 \mathrm{~m}$ and has vertical drop-offs along its western and northwestern edges. Courtship behavior of black grouper was witnessed (senior author, personal observ.) in an area characterized by a steep reef wall and large rock promontory.

\section{Passive acoustic recording}

Digital spectrogram recorders (DSG-Ocean ${ }^{1}$, Loggerhead Instruments, Sarasota, FL) were deployed at all 3 sites preceding aggregation of fish (Table 1). One digital spectrogram (DSG) recorder was deployed at the known FSA location at Mona Island. Multiple DSG

\footnotetext{
${ }^{1}$ Mention of trade names or commercial companies is for identification purposes only and does not imply endorsement by the National Marine Fisheries Service, NOAA.
}

\section{Table 1}

Dates of deployment and recovery of autonomous acoustic digital spectrogram recorders used for analysis of production of courtship-associated sounds made by black grouper (Mycteroperca bonaci) at 2 sites in Puerto Rico (Mona Island and Bajo de Sico) and 1 site off southern Florida (Riley's Hump) during 2012-2014. Deployment and recovery specifically refer to beginning and end dates of time-series data used in analysis.

\begin{tabular}{llcc}
\hline Year & Site & Deployment & Recovery \\
\hline \multirow{2}{*}{2012} & Mona Island & $12 / 20 / 11$ & $4 / 30 / 12$ \\
& Riley's Hump & $12 / 18 / 11$ & $5 / 29 / 12$ \\
2013 & Mona Island & $12 / 20 / 12$ & $4 / 30 / 13$ \\
& Bajo de Sico & $12 / 16 / 12$ & $4 / 30 / 13$ \\
2014 & Mona Island & $12 / 28 / 13$ & $4 / 30 / 14$ \\
& Bajo de Sico & $12 / 20 / 13$ & $4 / 30 / 14$ \\
& & & \\
\hline
\end{tabular}

recorders were deployed around the spawning areas at Riley's Hump and Bajo de Sico. For each of those 2 sites, data from the DSG recorder with the most CAS recordings were used for analysis. High CAS rates, high sound levels, and temporal patterns of CASs from each selected DSG recorder indicate a strong likelihood of close proximity to a spawning location.

The DSG recorders at Bajo de Sico and Mona Island collected 20-s audio clips every 5 min during deployment (Table 1). At Riley's Hump, the DSG recorder collected 10-s audio clips every 10 min during deployment (Table 1). Differences in these recording schedules required different corrective factors to extrapolate total CASs from sample size to daily totals for comparison. Daily total recorded CASs at Riley's Hump were multiplied by 60 to calculate the total number of CASs per day. Daily total recorded CASs at Bajo de Sico and Mona Island were multiplied by 15 to calculate total number of CASs per day. After recovery of DSG recorders, recorded files were downloaded and converted to .wav format for visual analysis with Ishmael software, vers. 2.4 (Cooperative Institute for Marine Resources Studies Bioacoustics Lab, Oregon State University, Newport, OR) (Fig. 2). Any questionable CASs were verified audibly by using Windows Media Player and noise cancelling headphones. Audible detection of a pulse train undulation that was specific to black grouper at a frequency band between 75 and $100 \mathrm{~Hz}$ served as species verification.

\section{Temporal analysis}

The total number of CASs per day from each DSG recorder was calculated for each calendar day during deployment. The monthly averages of daily total numbers of CASs were compared to confirm seasonality. Daily total numbers of CASs were analyzed in relation to the number of days after a full moon (DAFM) to analyze patterns associated with lunar periodicity. 


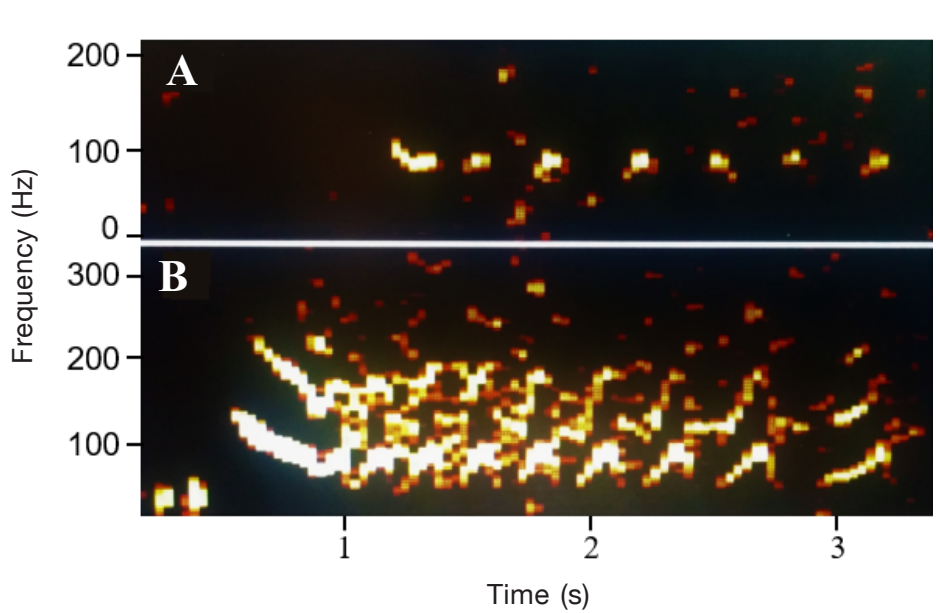

Figure 2

Examples of (A) strong and (B) weak spectrograms of courtshipassociated sounds (CASs) made by black grouper (Mycteroperca bonaci) and collected by a digital spectrogram recorder at Bajo de Sico, Puerto Rico, in 2013. Presence of pulse train undulation specific to black grouper within the frequency band of $75-100 \mathrm{~Hz}$ is visually detectable in both spectrograms. The $x$-axis is time in seconds. The $y$-axis is frequency in hertz. Brightness of yellow color indicates increased strength of CAS call.

morphometric analysis, the specific location of each DSG recorder that supplied data used in acoustics analysis was considered the location of the FSA. That point location was overlaid on high-resolution multibeam bathymetry maps for Bajo de Sico and Mona Island (Battista ${ }^{2}$ ). A 1-km-radius buffer around the location of the recorder was isolated from the bathymetry map. Depth was converted to slope and slope was extracted into contours. Slope contours were superimposed on depth. The "shelf edge" was classified as the continuous $20^{\circ}$-slope contour at a steep vertical depth profile off the shallower structure. The structure outlined within the $1-\mathrm{km}$ buffer area was used to visually identify promontories along the shelf edge. A promontory was defined as a noticeable convex protrusion extending off the contour of the shelf edge within the 1 -km-radius scale.

The morphometric parameters measured were the shortest distances from the FSA to 1 ) the shelf edge, 2) the 30-m depth contour, and 3) the horizontal inflection point defining the nearest promontory feature. The depth of the shelf edge was measured at its nearest point to the FSA location. The

The calendar day with a rising full moon (local time) was considered day 0 . Each successive day was considered another DAFM, until the next day of a rising full moon. Daily total numbers of CASs during periods of increased courtship calling were broken down into hour blocks. Hourly totals during these periods of increased activity were summed over the entire analysis period to examine daily patterns.

For each site, analysis of variation was done with Fisher's least significant difference test to determine differences between daily numbers of CASs for DAFM and hourly numbers of CASs for periods of increased activity.

\section{Temperature}

Temperature loggers (HOBO Water Temp Pro v2, Onset Computer Corp., Bourne, MA) were deployed at Mona Island and Bajo de Sico from 3 January to 31 April 2014. Temperature data from Mona Island was recorded at a spawning aggregation of red hind, nearby the spawning aggregation of black grouper, at a depth of 30 $\mathrm{m}$. Temperature data from Bajo de Sico was recorded at the site of a DSG recorder, nearby the spawning aggregation of black grouper, at a depth of $45 \mathrm{~m}$.

\section{Site geophysical features}

Geophysical features of the sites were analyzed by using the methods from Kobara and Heyman (2008). Analysis was done in ArcGIS 10.3 (Esri, Redlands, CA) with the Spatial Analyst and 3D toolboxes. For the aggregation of black grouper at Riley's Hump was not analyzed through bathymetric data; but the above parameters were read from an existing bathymetric map from Locascio and Burton (2016), originally published in Mallinson et al. (2003).

\section{Results}

\section{Temporal analysis}

Mona Island Mean daily CAS rates peaked in February for all 3 years, from 2012 through 2014, at Mona Island. Production of CASs increased between the last quarter moon and the new moon, from 8 to 14 DAFM (Table 2). Production of CASs increased between 8 and 12 DAFM (Fig. 3). CASs were correlated strongly with time of day (Table 3). During the 3 seasons at Mona Island, $54 \%$ of all recorded CASs by black grouper occurred during a 2-h period between 1700 and $1900 \mathrm{~h}$ local time (Fig. 4). The 4-h period between 1600 and 2000 h, $16 \%$ of the day, contained $68 \%$ of the total number of CASs produced (Fig. 4).

\footnotetext{
2 Battista, T. 2015. Water depth and acoustic backscatter data collected from NOAA Ship Nancy Foster in Caribbean Sea, southern coast of Isla de Mona, western coast of Puerto Rico from 2007-04-14 to 2007-04-24 (NCEI Accession 0131853). Version 1.1. NOAA National Centers for Environmental Information, Silver Spring, MD. [Data set available from website.]
} 


\section{Table 2}

Results of analysis of variance tests comparing the dependent variable mean number of courtship-associated sounds per day against the independent variable days after full moon for this study of acoustic courtship of black grouper (Mycteroperca bonaci) during 2012-2014 at Riley's Hump (RH) off southern Florida and at Mona Island (MI) and Bajo de Sico (BDS). $N=$ total number of days recorded. $\mathrm{df}=$ degrees freedom. $\mathrm{MS}=$ means squared.

\begin{tabular}{lcrrrr}
\hline Site and year & $N$ & df & MS & $F$ & $P$-value \\
\hline RH 2012 & 149 & 29 & 5.43 & 3.89 & $<0.0001$ \\
MI 2012 & 120 & 29 & 12.43 & 4.38 & $<0.0001$ \\
MI 2013 & 119 & 29 & 21.59 & 3.98 & $<0.0001$ \\
MI 2014 & 120 & 29 & 22.33 & 3.93 & $<0.0001$ \\
BDS 2013 & 119 & 29 & 4.74 & 2.06 & $<0.0001$ \\
BDS 2014 & 120 & 29 & 7.47 & 1.81 & 0.0178
\end{tabular}

\section{Table 3}

Results of analysis of variance tests comparing the dependent variable mean hourly numbers of courtship-associated sounds against the independent variable hour of day for this study of acoustic courtship of black grouper (Mycteroperca bonaci) during 2012-2014 at Riley's Hump (RH) off southern Florida and at Mona Island (MI) and Bajo de Sico (BDS). $N=$ hours of day (24)×number of months analyzed. $\mathrm{df}=$ degrees freedom. $\mathrm{MS}=$ mean square.

\begin{tabular}{lccrrr}
\hline Site and year & $N$ & df & \multicolumn{1}{c}{ MS } & \multicolumn{1}{c}{$F$} & $P$-value \\
\hline RH 2012 & 144 & 23 & 6.78 & 6.99 & $<0.0001$ \\
MI 2012 & 120 & 23 & 37.84 & 19.83 & $<0.0001$ \\
MI 2013 & 120 & 23 & 79.59 & 31.79 & $<0.0001$ \\
MI 2014 & 120 & 23 & 80.93 & 13.77 & $<0.0001$ \\
BDS 2013 & 120 & 23 & 2.78 & 2.34 & 0.0034 \\
BDS 2014 & 120 & 23 & 9.21 & 4.68 & $<0.0001$ \\
& & & & &
\end{tabular}

Riley's Hump The daily mean number of CASs peaked in April at Riley's Hump in 2012, increasing 2-fold from the month of lowest activity, February. Production of CASs increased from 7 to 11 DAFM, and peaked at 10 DAFM (Fig. 3). Daily production of CASs was correlated strongly with time of day (Table 3 ). Of all CASs at Riley's Hump, 35\% occurred in a $2-\mathrm{h}$ window from 1600 to $1800 \mathrm{~h}$ local time. Almost half (48\%) of all CASs occurred from 1500 to $1900 \mathrm{~h}$ local time (Fig. 4).

Bajo de Sico At Bajo de Sico, CAS counts were substantially lower than counts recorded at Mona Island and Riley's Hump. Daily mean number of CASs peaked in January. Production of CASs increased from 4 to 10 DAFM (Fig. 3) in 2013; however, no defined peak period was evident. In 2014, peaks were more defined. Production of CASs increased 6-9 DAFM (Fig. 3). Similar variation in hourly numbers of CASs was found between the 2 years at Bajo de Sico. Hour was determined to be significant (Table 3 ) for both years; however, patterns were more evident in 2014 (Fig. 4).

\section{Discussion}

\section{Temperature}

Temperature time-series data for 2014 indicated decreasing temperatures from January to March (Fig. 5). In March, temperatures remained near annual minimums before beginning to increase in April. At both Bajo de Sico and Mona Island, temperatures dropped below $27^{\circ} \mathrm{C}$ from mid-January to mid-April. Temperatures remained slightly lower at Bajo de Sico than at Mona Island but only by tenths of a degree Celsius, potentially a result of deployment of the temperature logger at a depth of $45 \mathrm{~m}$ at Bajo de Sico compared with deployment at a depth of $30 \mathrm{~m}$ at Mona Island.

\section{Site geophysical features}

All 3 spawning sites fell within the geophysical parameters described for multispecies FSAs in the Cayman Islands and Belize (Table 4). The Bajo de Sico and Mona Island spawning sites were less than $100 \mathrm{~m}$ from convex promontories, less than $100 \mathrm{~m}$ from the shelf edge, and in an area where the shelf edge is found at depths of 25-30 m. Similar geophysical parameters were evident at Riley's Hump. This site was situated at a depth of approximately 35 $\mathrm{m}$ and was adjacent to deep water $(>100 \mathrm{~m})$. All 3 sites were within 500 $\mathrm{m}$ of a $30-\mathrm{m}$ vertical wall.

The 3 spawning aggregations of black grouper had comparable patterns in their CAS production (Figs. 3 and 4) and site geophysical features (Table 4). Selected sites exhibited definable geophysical parameters that can be used to identify undocumented FSAs. In addition, distinct, well-defined, comparable patterns in CAS production were observed at 2 of the 3 FSAs analyzed in this study. Patterns of sound production at Mona Island were very similar over the 3 years. Seasonal timing of CAS production at Mona Island had little interannual variability, when examined in relation to DAFM and time of day, and was similar to temporal patterns observed at Riley's Hump. Elevated periods of CASs production at Riley's Hump were observed monthly during December-April, except January.

At Bajo de Sico, CAS temporal patterns varied between the 2 seasons during which passive acoustic recordings were collected. In 2013, there were periods of 


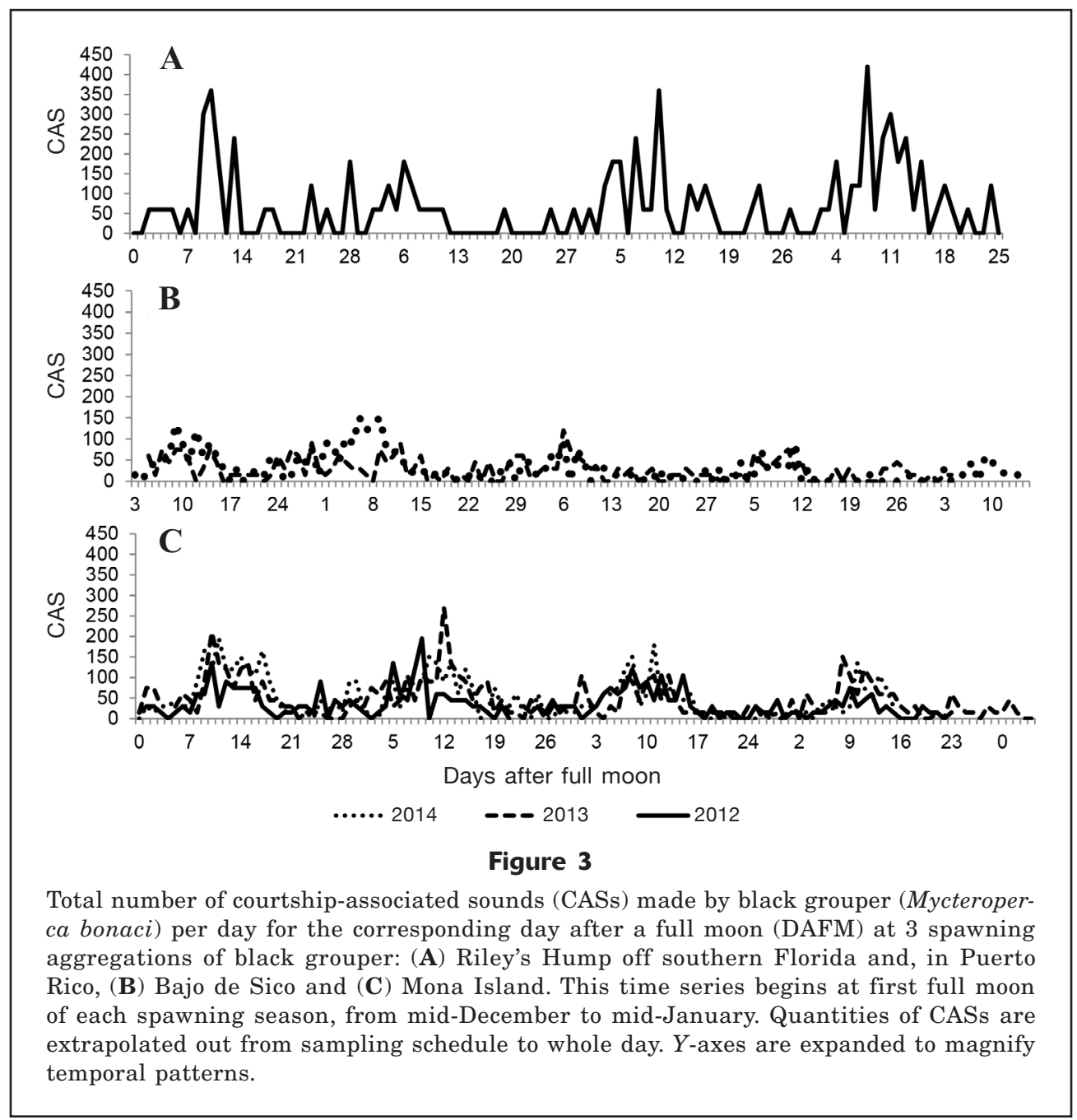

elevated CAS rates in January-April, but intraseasonal variability was low and lacked any definable patterns. In 2014, the CAS patterns at Bajo de Sico were similar to those observed at Mona Island and Riley's Hump. The production of CASs increased significantly on days approaching the last quarter and new moons during late afternoon hours. This shift indicates a change in the use of the study site by black grouper at Bajo de Sico, as CAS production here is considered an indirect measure for reproductive activity. Either the location was a spawning site during both seasons and the temporal dynamics changed between years, or, more probably but equally intriguing, Bajo de Sico was used only as a spawning location in 2014. This question needs to be addressed to better understand the local variations of temporal patterns at Bajo de Sico.

The monthly mean number of CASs per day coincided with the months of lowest annual temperature during 2014 at Mona Island and Bajo de Sico. In January, February, and March, average temperatures at these 2 sites were below $27^{\circ} \mathrm{C}$ before beginning a warming trend in late March. April was the first month with av- erage temperatures above $27^{\circ} \mathrm{C}$. Additionally, at Mona Island, the minimum temperature for 2014 occurred during February, the month with the highest CAS activity for all 3 years. Black grouper spawn in the temperature range of $25-28^{\circ} \mathrm{C}$ throughout their distribution. Within the greater Caribbean and Gulf of Mexico regions, FSAs form in winter months (García-Cagide and García, 1996; Eklund et al., 2000; Brulé et al., 2003; Paz and Sedberry, 2008; Schärer et al., 2014) when temperatures decrease to their annual minimums. In Bermuda, they occur during summer when sea-surface temperatures increase to $26-28^{\circ} \mathrm{C}$ (Luckhurst, 2010), and, in Brazil, the GSI index was highest during the winter months of August and September (Teixeira et al., 2004) when average temperatures cooled to $27^{\circ} \mathrm{C}$ (World Sea Temperatures, website). These temperature ranges have increased egg hatching success and larval survival of leopard grouper (Mycteroperca rosacea), Malabar grouper (Epinephelus malabaricus), and Nassau grouper (Epinephelus striatus) in controlled laboratory experiments (Watanabe et al., 1995; Gracia-López et al., 2004; Yoseda et al., 2006) and indicate that ocean 

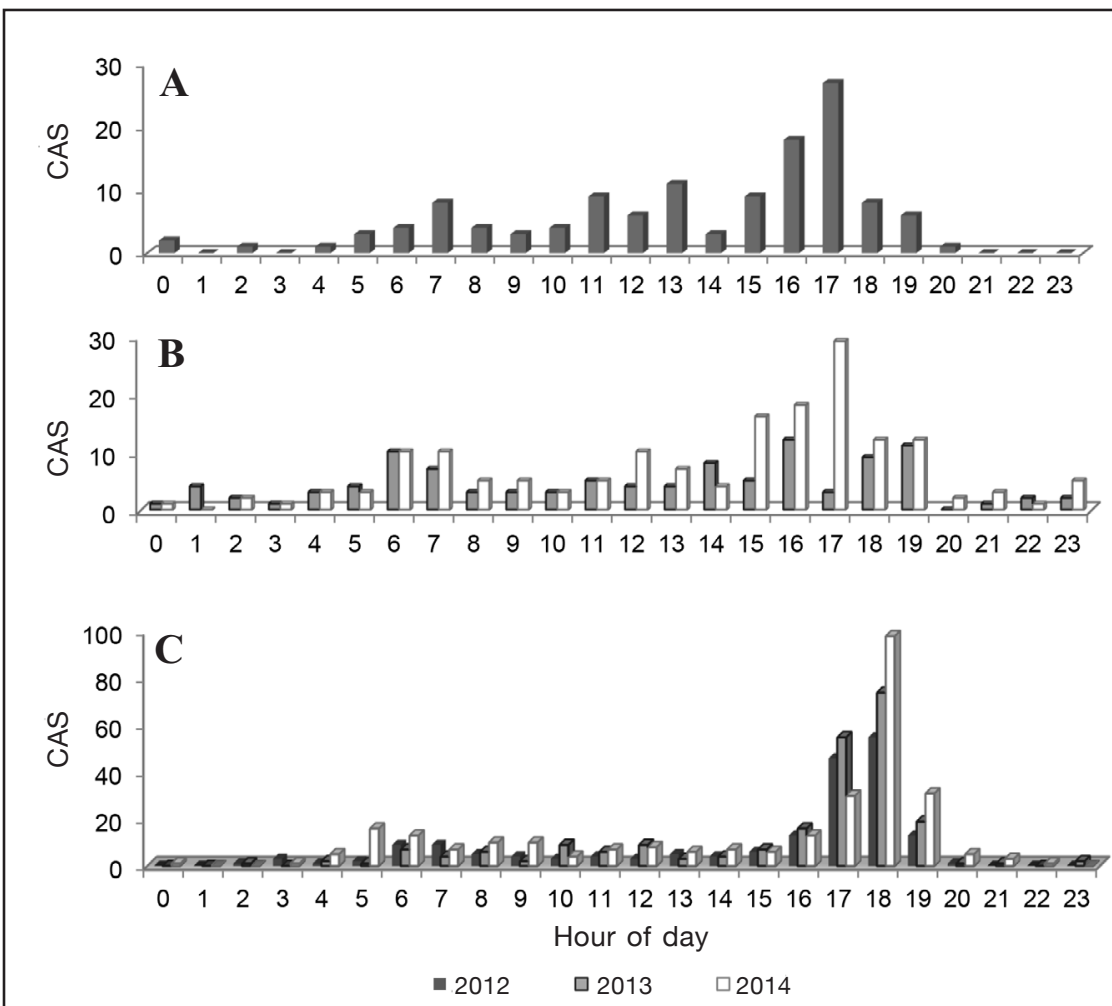

Figure 4

Total numbers of courtship-associated sounds (CASs) produced by black grouper (Mycteroperca bonaci) per hour summed during entire deployment at 3 spawning sites: (A) Riley's Hump off southern Florida and, in Puerto Rico, (B) Bajo de Sico and (C) Mona Island. Hourly totals are summed from days of increased spawning activity. All times are in local Atlantic Standard Time (-4GMT).

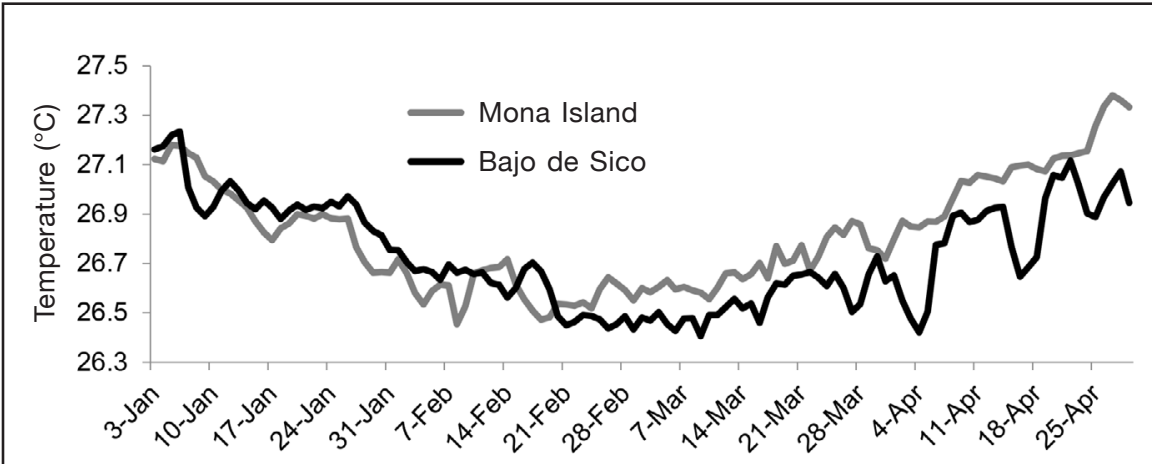

Figure 5

Time series of temperatures at Mona Island (30-m depth) and Bajo de Sico (45m depth) in Puerto Rico from 3 January to 30 April 2014.

temperatures are a seasonal controlling factor for the formation of spawning aggregations of black grouper.

The CAS rate increased significantly between the last quarter moon and the new moon at all 3 sites (Fig. 3 ). Between the last quarter and new moon, moonrise occurs after sunset. Furthermore, during these lunar stages, CAS production peaked during late afternoon hours (Fig. 4). More than half of all CASs produced over the 3 years at Mona Island occurred within a 2-h period around sunset. At Riley's Hump, almost half 


\begin{tabular}{|c|c|c|c|c|c|c|}
\hline \multicolumn{7}{|c|}{$\begin{array}{l}\text { Geophysical parameters of spawning aggregations of black grouper at Mona Island (MI) anc } \\
\text { Bajo de Sico (BDS) in Puerto Rico. Deployment location of digital spectrogram recorder } \\
\text { served as proxy for spawning aggregation site. An asterisk }(*) \text { indicates that the expectec } \\
\text { mean and standard deviation (SD) were calculated from sites that included a spawning ag } \\
\text { gregation of black grouper (Mycteroperca bonaci) seen in Table } 1 \text { in Kobara and Heymar } \\
(2010) \text {. }\end{array}$} \\
\hline & $\begin{array}{c}\text { Promontory } \\
\text { shape }\end{array}$ & $\begin{array}{l}\text { Promontory } \\
\text { orientation }\end{array}$ & $\begin{array}{l}\text { Shelf edge } \\
\text { depth }(\mathrm{m})\end{array}$ & $\begin{array}{c}\text { Distance } \\
\text { to shelf } \\
\text { edge }(\mathrm{m})\end{array}$ & $\begin{array}{c}\text { Distance to } \\
\text { inflection } \\
\text { point }(\mathrm{m})\end{array}$ & $\begin{array}{c}\text { Distance to } \\
\text { 100-m } \\
\text { depth }(\mathrm{m})\end{array}$ \\
\hline MI & Convex & South & 27 & 10 & 24 & 63 \\
\hline BDS & Convex & West & 28 & 19 & 94 & 233 \\
\hline Mean* & & & 36 & 25 & 127 & 59 \\
\hline $\mathrm{SD}^{*}$ & & & 10 & 25 & 94 & 35 \\
\hline
\end{tabular}

(40\%) of CASs were produced $1 \mathrm{~h}$ before sunset. It seems likely that courtship behavior, and presumably spawning, occurred mainly during the approaching low-light afternoons with no rising moon. This timing is shared by most large groupers in the western Atlantic (Colin at al., 1987; Sala et al., 2001; Schärer et al., 2012b; Locascio and Burton, 2016). Evolution of dusk spawning has been suggested to control predation on both spawning adults and larvae for species that form transient spawning aggregations (Johannes, 1978; Colin and Clavijo, 1988). Evening spawning could provide an approximate 12-h period of darkness for dispersal of eggs away from the aggregation site.

Tidal stage is directly related to moonrise. Beginning 9 DAFM, sunset coincides with the outgoing tide at Mona Island (NOAA Tides and Currents, website), increasing the likelihood that eggs are transported off the reef and away from egg predators (Johannes, 1978). Along the western insular shelf of Puerto Rico, tidal currents are thought to play an important role in spawning timing for the red hind (Appeldoorn et al., in press), and tides have been shown to correlate with spawning timing in other locations (Johannes, 1978; Heppell et al, 2008). Although the effects of light and current are confounded within a single site, they are not confounded across sites. Unlike the conditions at Mona Island and Bajo de Sico, CAS peaks at Riley's Hump did not coincide precisely with sunset hours but occurred slightly earlier. However, the exact time of spawning and the patterns of current flow at Riley's Hump are not known, and current flows can be widely variable because of variations in the location of the Florida current. The significance of this offset and the relative effects of light and currents as factors controlling spawning need further study.

At Mona Island, black grouper aggregate around a specific geological feature. Whether this site is the actual location of spawning or a part of a larger courtship arena (Nemeth, 2012) is unknown. Dive surveys were not conducted in this study during early evening hours, the time at which spawning has been observed in Belize (Sala et al., 2001; Paz and Sedberry, 2008). However, the significant increases in CAS rates during the hours of dusk indicate that spawning was occurring, at least, nearby. This CAS pattern indicates that the aggregation forms within close proximity of the location of the DSG recorder-a conclusion that coincides with the morphometric analysis of nearby geological features (Table 4).

The DSG recorder at Mona Island was deployed 10 $\mathrm{m}$ from the shelf edge and sat at a depth of $30 \mathrm{~m}$. Off the shelf edge, there is a step feature, where the bottom briefly levels out at $40 \mathrm{~m}$ before a second steep slope. Within $25 \mathrm{~m}$ of the DSG recorder is a promontory along the shelf edge. All features are consistent with morphometric parameters of multispecies spawning aggregations in the Cayman Islands and Belize (Kobara and Heyman, 2008; 2010). These features are also common to Bajo de Sico and indicate similar geophysical characteristics for FSA site selection. Although some variation exists within the geomorphology at spawning aggregations of black grouper (Paz and Sedberry 2008; Luckhurst, 2010), similar morphometric parameters have been observed for many documented FSAs, and these parameters can be used to potentially identify new FSAs (Kobara and Heyman, 2010).

Transient FSAs provide an opportunity to survey the density and health of fish stocks for what are normally considered solitary species (Gannon, 2008; Luczkovitch et al., 2008). Including those in our study, only 4 spawning aggregations of black grouper have been identified in U.S. territorial waters; the largest one is composed of only a couple hundred individuals (Eklund et al, 2000; Schärer et al., 2014; Locascio and Burton, 2016). However, population numbers indicate that black grouper must be spawning at additional sites. Anecdotal evidence of eight additional spawning aggregations of black grouper in Puerto Rico, based on interviews with fisherman, suggests that many other sites must exist, although only 
the 1 site at Mona Island has been verified (OjedaSerrano et al., 2007).

Strong regularities in temporal patterns in CAS production between 2 geographically separate sites, Mona Island and Riley's Hump, indicate that spawning timing of black grouper is predictable within the greater Caribbean region. Interannual monitoring at Mona Island adds support to these consistencies in temporal patterns. Whether these patterns are population wide will be determined only through further analysis and the incorporation of additional sites within a monitoring program. Identifying new FSAs and developing fine-resolution behavioral models can identify local variations in temporal patterns of spawning behavior and assist in the development of effective management policies.

\section{Acknowledgments}

Funding and assistance was provided by the Caribbean Coral Reef Institute, Department of Marine Sciences, of the University of Puerto Rico and the Puerto Rico Department of Natural and Environmental Resources. This study was also funded by a grant from the Coral Reef Conservation Program, NOAA, project number 2025-2010. Field assistance was provided by the crews of the Orca Too, Tourmarine, and MV Spree, as well as individuals from the Department of Marine Sciences, University of Puerto Rico Recinto de Mayaguez, and the Southeast Fisheries Science Center of the National Marine Fisheries Service.

\section{Literature cited}

Appeldoorn, R. S., M. T. Schärer, K. Clouse, T. J. Rowell, L. Cherubin, and S. Suman.

In press. Spatio-temporal patterns of red hind, Epinephelus guttatus, spawning aggregations off the west coast of Puerto Rico: evidence from monitoring courtship associated sounds. Proc. Gulf Caribb. Fish. Inst. 68.

Brulé, T., X. Renán, T. Colás-Marrufo, Y. Hauyon, and A. N. Tuz-Sulub.

2003. Reproduction in the protogynous black grouper (Mycteroperca bonaci (Poey)) from the southern Gulf of Mexico. Fish. Bull. 101:463-475.

Claydon, J.

2004. Spawning aggregations of coral reef fishes: characteristics, hypotheses, threats and management. Oceanogr. Mar. Biol., Annu. Rev. 42:265-302.

Colin P. L., and I. E. Clavijo.

1988. Spawning activity of fishes producing pelagic eggs on a shelf edge coral reef, southwestern Puerto Rico. Bull. Mar. Sci. 43:249-279.

Colin, P. L., D. Y. Shapiro, and D. Weiler.

1987. Aspects of the reproduction of two groupers, Epinephelus guttatus and $E$. striatus in the West Indies. Bull. Mar. Sci. 40:220-230.

Crabtree, R. E., and L. H. Bullock.

1998. Age, growth, and reproduction of black grouper,
Mycteroperca bonaci, in Florida waters. Fish. Bull. 96:735-753.

Domeier, M. L., and P. L. Colin.

1997. Tropical reef fish spawning aggregations: defined and reviewed. Bull. Mar. Sci. 60:698-726.

Eklund, A.-M., D. B. McClellan, and D. E. Harper.

2000. Black grouper aggregations in relation to protected areas within the Florida Keys National Marine Sanctuary. Bull. Mar. Sci. 66:721-728.

Ferreira, B. P., L. Rocha, A. L. B. Gaspar, Y. Sadovy, and M. Craig.

2008. Mycteroperca bonaci. IUCN Red List of Threatened Species 2008: e.T132724A3433339. [Available from website.]

Frank, E. F., C. Wicks, J. Mylroie, J. Troester, E. C. Alexander Jr., and J. L. Carew.

1998. Geology of Isla de Mona, Puerto Rico. J. Caves Karst Stud. 60:69-72.

Gannon, D. P.

2008. Passive acoustic techniques in fisheries science: a review and prospectus. Trans. Am. Fish. Soc. 137:638-656. Article

García-Cagide, A., and T. García.

1996. Reproduccion de Mycteroperca bonaci y Mycteroperca venenosa (Pisces: Serranidae) en la plataforma cubana. Rev. Bio. Trop. 44:771-780.

Gracia-López, V., M. Kiewek-Martínez, and M. MaldonadoGarcía.

2004. Effects of temperature and salinity on artificially reproduced eggs and larvae of the leopard grouper $M y c$ teroperca rosacea. Aquaculture 237:485-498. Article

Heppell, S. A., B. X. Semmens, C. V. Pattengill-Semmens, P. G. Bush, B. C. Johnson, C. M. McCoy, C. Paris, J. Gibb, and S. S. Heppell.

2008. Tracking potential larval dispersal patterns from Nassau grouper aggregation sites: evidence for local retention and the "importance of place." Proc. Gulf Caribb. Fish. Inst. 61:325-327.

Johannes, R. E.

1978. Reproductive strategies of coastal marine fishes in the tropics. Environ. Biol. Fish. 3:65-84. Article

Kobara, S., and W. D. Heyman.

2008. Geomorphometric patterns of Nassau grouper (Epinephelus striatus) spawning aggregation sites in the Cayman Islands. Mar. Geod. 31:231-245. Article

2010. Sea bottom geomorphology of multi-species spawning aggregation sites in Belize. Mar. Ecol. Prog. Ser. 405:243-254. Article

Locascio, J. V., and M. L. Burton.

2016. A passive acoustic survey of fish sound production at Riley's Hump within Tortugas South Ecological Reserve: implications regarding spawning and habitat use. Fish. Bull. 114:103-116. Article

Luckhurst, B. E.

2010. Observations of a black grouper (Mycteroperca bonaci) spawning aggregation in Bermuda. Gulf Caribb. Res. 22:43-49. Article

Luczkovich, J. J., D. A. Mann, and R. A. Rountree. 2008. Passive acoustics as a tool in fisheries science. Trans. Am. Fish. Soc. 137:533-541. Article

Mallinson, D., A. Hine, P. Hallock, S. Locker, E. Shinn, D. Naar, B. Donahue, and D. Weaver.

2003. Development of small carbonate banks on the south Florida platform margin: response to sea level and climate change. Mar. Geol. 199:45-63. Article 
Mann, D. A., J. V. Locascio, F. C. Coleman, and C. C. Koenig. 2009. Goliath grouper Epinephelus itajara sound production and movement patterns on aggregation sites. Endang. Species Res. 7:229-236. Article

Mann, D., J. Locascio, M. Schärer, M. Nemeth, and R. Appeldoorn.

2010. Sound production by red hind Epinephelus guttatus in spatially segregated spawning aggregations. Aquat. Biol. 10:149-154. Article

Matos-Caraballo, D.

1997. Status of the groupers in Puerto Rico, 197095. Proc. Gulf Caribb. Fish. Inst. 49:340-353.

Nelson, M. D., C. C. Koenig, F. C. Coleman, and D. A. Mann. 2011. Sound production of red grouper Epinephelus morio on the west Florida shelf. Aquat. Biol. 12:97-108. Article

Nemeth, R. S.

2012. Ecosystem aspects of species that aggregate to spawn. In Reef fish spawning aggregations: biology, research and management (Y. Sadovy de Mitcheson and P. L. Colin, eds.), p. 21-55. Springer, New York.

Ojeda-Serrano, E., R. S. Appeldoorn, and I. Ruiz-Valentin.

2007. Reef fish spawning aggregations of the Puerto Rican shelf. Proc. Gulf Caribb. Fish. Inst. 59:467-474.

Paz, H., and G. R. Sedberry.

2008. Identifying black grouper (Mycteroperca bonaci) spawning aggregations off Belize: conservation and management. Proc. Gulf Caribb. Fish. Inst. 60:577-584.

Rowell, T. J., R. S. Appeldoorn, J. A. Rivera, D. A. Mann, T. Kellison, M. Nemeth, and M. Schärer-Umpierre.

2011. Use of passive acoustics to map grouper spawning aggregations, with emphasis on red hind, Epinephelus guttatus, off western Puerto Rico. Proc. Gulf Caribb. Fish. Inst. 63:139-142.

Rowell, T. J., R. S. Nemeth, M. T. Schärer, and R. S. Appeldoorn. 2015. Fish sound production and acoustic telemetry reveal behaviors and spatial patterns associated with spawning aggregations of two Caribbean groupers. Mar. Ecol. Prog. Ser. 518:239-254. Article
Sala, E., E. Ballesteros, and R. M. Starr.

2001. Rapid decline of Nassau grouper spawning aggregations in Belize: fishery management and conservation needs. Fisheries 26(10):23-30. Article

Schärer, M. T., M. I. Nemeth, D. Mann, J. Locascio, R. S. Appeldoorn, and T. J. Rowell.

2012a. Sound production and reproductive behavior of yellowfin grouper, Mycteroperca venenosa (Serranidae) at a spawning aggregation. Copeia 1:135-144. Article

Schärer, M. T., T. J. Rowell, M. I. Nemeth, and R. S Appeldoorn. $2012 \mathrm{~b}$. Sound production associated with reproductive behavior of Nassau grouper Epinephelus striatus at spawning aggregations. Endang. Species Res. 19:29-38. Article

Schärer, M. T., M. I. Nemeth, T. J. Rowell, and R. S. Appeldoorn. 2014. Sounds associated with the reproductive behavior of the black grouper (Mycteroperca bonaci). Mar. Biol. 161:141-147. Article

Teixeira, S. F., B. P. Ferreira, and I. P. Padovan.

2004. Aspects of fishing and reproduction of the black grouper Mycteroperca bonaci (Poey, 1860) (Serranidae: Epinephelinae) in the northeastern Brazil. Neotrop. Ichthyol. 2:19-30. Article

Watanabe, W. O., C.-S. Lee, S. C. Ellis, and E. P. Ellis.

1995. Hatchery study of the effects of temperature on eggs and yolksac larvae of the Nassau grouper Epinephelus striatus. Aquaculture 136:141-147. Article

Weaver, D. C., D. F. Naar, and B. T. Donahue.

2006. Deepwater reef fishes and multibeam bathymetry of the Tortugas South Ecological Reserve. In Emerging technologies for reef fisheries research and management (J. C. Taylor, ed.), p. 48-68. NOAA Professional Paper NMFS 5.

Yoseda, K., S. Dan, T. Sugaya, K. Yokogi, M. Tanaka, and S. Tawada.

2006. Effects of temperature and delayed initial feeding on the growth of Malabar grouper (Epinephelus malabaricus) larvae. Aquaculture 256:192-200. Article 